\title{
Er det riktige det viktige? Literacy-syn og kvalitetstrekk i kommersielle abc-apper for norskspråklige førskolebarn
}

\author{
Gunhild Kvåle \\ Universitetet $i$ Agder
}

\begin{abstract}
Sammendrag
Artikkelen undersøker literacy-syn og kvalitetstrekk i abc-apper fra kommersielle produsenter ved å analysere ni abc-apper for norskspråklige førskolebarn. Undersøkelsen er teoretisk forankra i sosiokulturell literacy-forskning og sosialsemiotiske perspektiver på multimodalitet og semiotisk teknologi. Analysen viser at appene domineres av sju typer literacy-aktiviteter: bokstav-lyd-kopling, bokstavutforming, staving, hukommelsesaktiviteter, tekstproduksjon, lesing og sang. For hver av disse aktivitetene identifiseres det trekk som bidrar til å svekke eller styrke kvaliteten, totalt tretten trekk. I diskusjonen reflekteres det over hva slags literacy-forestillinger appene er innskrevet med, deriblant over korrekt/ukorrekt-dimensjonens sentrale posisjon. Det diskuteres også hvordan kvaliteten i appene i flere tilfeller får svekka kvalitet som følge av at aktørene i begrensa grad utnytter samfunnets kunnskapsbase. Artikkelen peker avslutningsvis på det store mulighetsrommet for utvikling av gode abc-apper for målgruppa.
\end{abstract}

Nøkkelord: Abc-apper; abc-ressurser; abc-materiell; førskolebarn; kommersielle lceringsressurser; teknologi; kvalitet

\begin{abstract}
Is the right the best? Literacy views and quality features in commercial abc apps for Norwegian pre-school children

This paper investigates literacy views and quality features in abc apps from commercial producers by analysing nine abc apps for Norwegian pre-school children. The study is theoretically informed by sociocultural literacy studies and multimodal social semiotic technology studies. The analysis shows that the apps include mainly seven literacy activitites: 1) connecting letters and sounds, 2) shaping letters, 3) spelling, 4) memory activities, 5) free text production, 6) reading, and 7) singing. Quality features are identified for each of these activitites, in total thirteen features. The discussion reflects on the literacy ideas that are inscribed in the apps, including the prominent role of correct/incorrect. It also discusses how quality in several instances become weakened due to limited exploitation of available knowledge on literacy. Finally, the article addresses some possibilities for the future development of good abc apps for pre-school children.
\end{abstract}

Korrespondanse: Gunhild Kvåle, Universitetet i Agder, epost: gunhild.kvale@uia.no

(C) 2020 G. Kvåle. This is an Open Access article distributed under the terms of the Creative Commons Attribution 4.0 International License (https://creativecommons.org/licenses/by-nc/4.0/), allowing third parties to copy and redistribute the material in any medium or format and to remix, transform, and build upon the material for any purpose, even commercially, provided the original work is properly cited and states its license.

Citation: G. Kvåle. "Er det riktige det viktige? Literacy-syn og kvalitetstrekk $i$ kommersielle abc-apper for norskspråklige førskolebarn" Nordic fournal of Literacy Research, Vol. 6(1), 2020, pp. 6-25. http://dx.doi.org/10.23865/njlr.v6.1746 
Keywords: Abc apps; abc resources; learning technology; educational technoloy; semiotic technology; app quality

Responsible editor: Atle Skaftun

Received: June, 2019; Accepted: December, 2019; Published: February, 2020

\section{Introduksjon}

Appstore tilbyr apper til norskspråklige førskolebarn i mange sjangrer, deriblant $a b c-$ apper. Abc-apper er i likhet med abc-bøker og andre abc-ressurser kjennetegna av at innhold, funksjon og form er retta mot å utvikle ulike aspekter ved det flettverket av ferdigheter, kunnskaper og holdninger som man i dagligtalen kaller «å lære å lese og skrive» hos barn før og rundt skolestartsalder. Det har i flere århundrer har vært et kommersielt marked for abc-ressurser (Skyggebjerg, 2018), og abc-appene som blir undersøkt i denne artikkelen er utgitt av nettopp kommersielle aktører. De kan være alt fra store internasjonale selskap til norske enkeltpersonforetak, men har fellesnevner $\mathrm{i}$ at de ikke kan antas å ha en instans som gir en faglig kvalitetssikring av appene samt at produktene deres ikke er spesifikt utvikla for å fungere som læremidler i opplæringsinstitusjoner. I en tid der nettbrett har blitt et svært populært medium blant førskolebarn og der omsorgspersoner i barnehager og hjem gjerne vil tilby barna «gode» apper, er det vesentlig å utvikle kunnskap om hvordan abc-apper er bygd opp, og om hvordan kvalitet kan forstås i slike apper.

Det er mange aktiviteter som en app-produsent kan velge å inkludere, men i en utgitt app vil det nødvendigvis alltid være gjort et utvalg. De mange små og store valgene som tas $\mathrm{i}$ designen av en app, har konsekvenser for appens kvalitet som literacy-ressurs. Utvalget og organiseringa av aktivitetene i en abc-app gir dermed innsikt i hva slags syn på literacy og kvalitet produsenter har. Literacy-forskeren David Barton kaller det «literacy-teorier»: "different ideas of 'the problem' and what should be done about it» (Barton, 2007, s. 2). Literacy-teoriene til kommersielle appprodusenter setter rammer for hvilke literacy-erfaringer som barna kan gjøre gjennom en app, og de skaper forventninger hos app-kjøpere til hva abc-apper skal og bør romme. Kommersielle app-produsenter setter på denne måten viktige premisser for hvordan literacy-aktiviteter utfolder seg på nettbrett, både hjemme og i barnehagen, og for hvordan de kan utfolde seg.

Denne undersøkelsen har tre hovedmål. For det første vil artikkelen bidra til økt kunnskap om kommersielle abc-apper for norskspråklige førskolebarn. For det andre vil artikkelen bidra til økt innsikt i kommersielle aktørers literacy-teorier. For det tredje sikter undersøkelsen mot å forsterke refleksjonsgrunnlaget om hva som styrker og svekker abc-appers kvalitet. For å nå disse målene identifiserer jeg hvilke literacy-aktiviteter et utvalg kommersielle abc-apper for førskolebarn består av og hvilke kvalitetstrekk de ulike aktivitetene aktualiserer, samt diskuterer hvordan vi kan forstå aktørenes literacy-teorier i en større kulturell sammenheng. 


\section{G. Kvåle}

\section{Førskolebarn og abc-ressurser}

Appene i denne studien er ikke spesifikt retta mot pedagogisk arbeid i barnehager, men siden faglitteratur om abc-ressurser som oftest har tilknytning til opplæringsinstitusjonene, er faglige perspektiver på skriftspråkarbeid i barnehagen, og også skolens begynneropplæring, likevel relevant. Allerede den første rammeplanen, som kom i 1996, ga barnehagen et ansvar for skriftspråkarbeid:

Å tilegne seg lese- og skriveferdigheter er en langvarig prosess som starter lenge før den formelle lese- og skriveopplæringen i skolen tar til. Et felles kjennetegn for tidligere lesere er at barna har fått mange og varierte erfaringer med skriftspråk i tidlig alder. ... Barna bør oppmuntres til å skrive bokstaver og tallsymboler og leke med skriftspråket. ... Det viktigste er imidlertid at barna lærer seg å leke med og har glede av å eksperimentere med språket. (Barne- og familiedepartementet, 1996, s. 80f)

Sitatet viser at det i barnehagetradisjonen har blitt lagt vekt på en utforskende og lekende tilnærming, med barnets opplevelse av mening, skrivelyst og leselyst i sentrum. Denne tilnærminga er videreført i de senere rammeplanene (Kunnskapsdepart-ementet 2006, 2017) og reflekteres også i faglitteraturen, deriblant i Anne Høigårds innflytelsesrike fagbok Barns språkutvikling - muntlig og skriftlig (2013). Videre blir førskolebarnas utforskende skriving ofte løfta fram, både den barneinitierte (Hagtvet, 2004; Laursen, 2009; Smidt, 2013) og den voksenintierte. Den norske literacy-nestoren Ruth Trøite Lorentzen har i mange arbeid også vist betydninga av samspillet mellom dem (f.eks. Lorentzen, 1997). Faglitteraturen legger også vekt på at «korrekt» lesing og skriving, så som beherskelse av ortografiske regler, ikke er viktig i de tidlige fasene av skriveutviklinga. I én fagbok formuleres det slik: «Én regel bør imidlertid etter vår og mange andres mening være absolutt: En skal overhodet ikke rette på barnet i denne perioden! Det er både en svært viktig og svært sårbar periode i skriveutviklingen, og en må ikke ta motet fra barna» (Valvatne \& Sandvik, 2007, s. 265).

Barnehagefeltets vekt på å skape og styrke barns skrive- og leselyst gjennom uforskning og lek deles delvis av skolefeltet (f.eks. Traavik, Ulland \& Bjørkvold, 2013, men begynneropplæringa legger i tillegg stor vekt på kognitive aspekter, så som avkoding og forståelse, syntese og analyse, bokstavkunnskap og språklig (særlig fonologisk) bevissthet (Kulbrandstad, 2018). Det viser seg i praksisfeltet blant anna ved at bokstaver betegnes med deres lyd, og ikke deres navn. Tradisjonelt har også opplæring i håndskrift vært en viktig del av skolens arbeid med bokstavlæring (Hekneby, 2011; Selås, 2018). Arbeid med kognitive dimensjoner og håndskrift inngår også i mange barnehagers arbeid, men i større grad på barnas egne, lekende premisser. Ulikt skolen har barnehager heller ikke lærebøker eller læreplaner.

Lese- og skriveopplæringa er både $\mathrm{i}$ barnehage og skole tett kopla sammen med litteraturarbeid. Det gjelder i særlig grad dikt, rim og regler, siden språkets poetiske og estetiske egenskaper er vesentlige for å styrke barnas språklige bevissthet.

Det foreligger, så langt jeg har kunnet se, lite forskning på abc-materiell for førskolebarn, men Magnhild Vollan har i flere studier undersøkt kvalitet i kommersielle 
papirbaserte abc-ressurser. I en undersøkelse av to bok- og bildekortpakker fra Spektrum forlag identifiserer hun tre problemområder (Vollan, 2010a). Det første er at bildene ikke alltid gir god kontekstuell støtte, samtidig som de ofte har en verbal «fasit». Det andre gjelder tilretteleggelegginga for norske språkforhold, deriblant problemet med bruk av lydstridige ord som geit for bokstaven $g$. Hun peker for det tredje på utfordringer ved den didaktiske tilrettelegginga, deriblant at «streng fokusering på «riktig» ord vil være lite formålstjenlig for målgruppa» (Vollan, 2010a, s. 275). Vollan (2010b) har videre sett på de såkalte Gullstjerne-bøkene, også de fra Spektrum forlag, som er aktivitetshefter for barn i alderen 4-9 år til bruk utenfor opplæringsinstitusjonene som lover "enkel og morsom læring». Vollan identifiserer flere problematiske egenskaper ved heftenes kvalitet som literacy-ressurser. Hun peker på at innholdet rommer aktiviteter som er "uvanlige i begynneropplæringa» (s. 195), så som arbeid med flertallsmarkering av substantiv i heftet for 4-6-åringer (s. 196). Hun trekker fram det problematiske ved at $k i+r k e$ og $s n+e g l$ omtales som «stavelser», og at betegnelsen «ending» knyttes til -ing i ordforma ring. 4-6-åringene gis flere oppgaver om krevende ortografi, for eksempel staving av ord som starter med $k i / k y$ og $s k j / s k$. Hun peker også her på utfordringer med bildene, og på mangelfull tilpasning til norske språkforhold. Konklusjonen uttrykkes tydelig: «De er i liten grad tilrettelagt for å gi barn i målgruppen enkel og morsom læring, i tråd med læringsmålene» (s. 212).

Så vidt jeg har kunnet se, har det ikke blitt gjort sammenliknbare studier av kommersielle digitale abc-ressurser. I forskning som tematiserer kvalitet i læringsprogramvare ("educational software») har diskusjonene, så langt jeg har sett, dreid seg appers generelle pedagogiske kvalitet (Dezuanni, 2015; McManis \& Gunnewig, 2012). Jeg har ikke funnet forskning som eksplisitt behandler literacy-syn og kvalitet i digitale abc-ressurser for førskolebarn. Denne studien bidrar slik til å utfylle og supplere eksisterende forskning.

\section{Literacy, multimodalitet og semiotisk teknologi}

Artikkelen skriver seg inn i den sosiokulturelle literacy-forskningas interesse for lesing og skriving som sosialt og kulturelt situerte prosesser. Barton (2007) skiller mellom «literacy events» og "literacy practices». Literacy-hendelser forstås som "the particular activities where literacy has a role» (s. 37), mens literacy-praksiser dreier seg om "the general cultural ways of utilizing literacy which people draw upon in a literacy event» (s. 37), altså de kulturelle praksisene som ligger til grunn for konkrete literacy-hendelser og som samtidig utgjør summen av dem. Abc-apper blir i denne studien forstått som partiturer for literacy-hendelser, og dette partituret er bygd opp av det jeg kaller literacy-aktiviteter. Literacy-aktiviteter viser altså til de konkrete, men enda ikke sosialt realiserte oppgavene som app-designen tilbyr barna.

Andre uttrykksformer enn skrift, særlig bilder, har historisk vært viktige i abcressurser, blant anna for deres særegne kombinasjon av didaktikk og estetikk (Skjelbred, 2017; Skyggebjerg, 2018). I abc-apper kombineres ulike visuelt og 


\section{G. Kvåle}

auditivt medierte uttrykksformer, og undersøkelsen har derfor en multimodal forankring. Flere tidligere studier av førskolebarns literacy har hatt en multimodal tilnærming (jf. Semundseth \& Hopperstad, 2013), ofte med et sosialsemiotisk utgangspunkt (Kress \& Jewitt, 2003; Laursen, 2009; Tønnessen \&Vollan, 2010). Også denne studien er posisjonert innenfor den sosialsemiotiske forskningstradisjonen.

Sosialsemiotisk multimodalitetsforskning har tradisjonelt gitt systematiske beskrivelser av semiotiske ressurser og hvordan de er sosialt regulert (van Leeuwen, 2005), men har i de siste åra blitt utvida til også å omfatte semiotiske teknologier (se f.eks. Djonov \& van Leeuwen, 2011, 2018; Zhao, Djonov og van Leeuwen, 2014). Den analytiske oppmerksomheten skifter dermed fra valg av semiotiske ressurser på de multimodale tekstoverflatene til meningsvalg i teknologiene som ligger «under» overflaten. Interessen retter gjerne mot hvordan ideologiske antakelser og normer er innskrevet i programvarer og annen teknologi, og setter premisser for bruk av den aktuelle teknologien (Poulsen, Kvåle \& van Leeuwen, 2018, s. 594).

Semiotiske teknologier omfatter ifølge sosialsemiotikerne Zhao, Djonov og van Leeuwen (2014) to hoveddimensjoner: 1) semiotiske artefakter kopla til 2) semiotiske praksiser. Figur 1 visualiserer disse relasjonene for abc-apper.

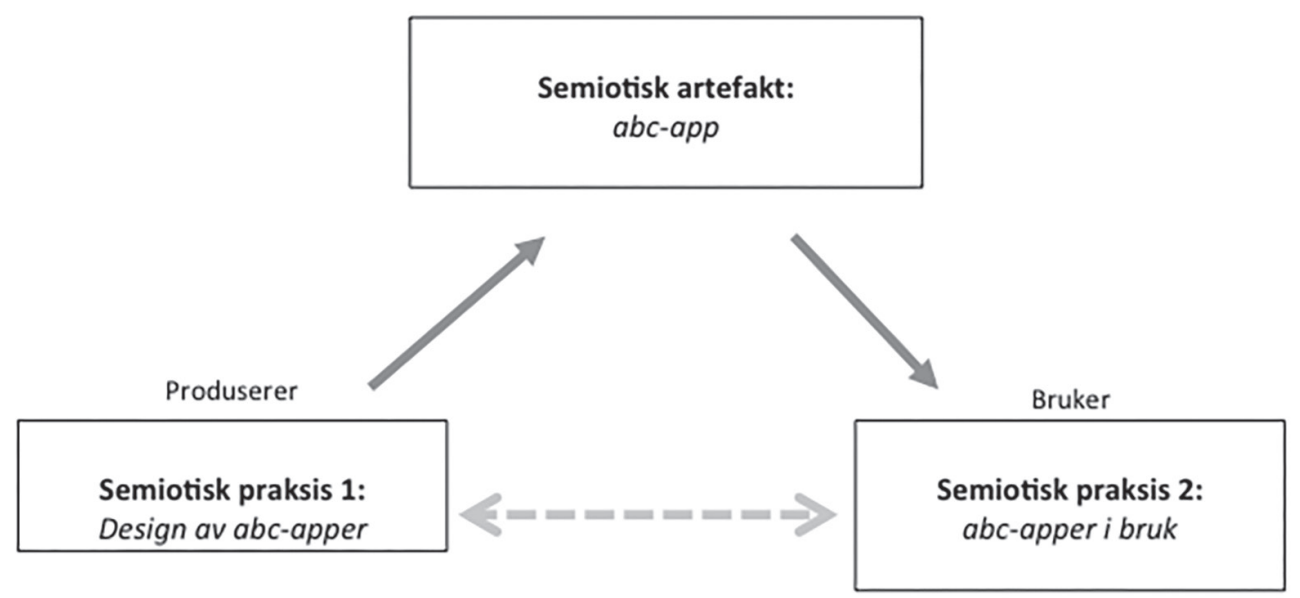

Figur 1. Abc-apper som semiotiske artefakter og praksiser. Inspirert av Zhao, Djonov \& van Leeuwen, 2014.

Figuren viser at abc-apper inngår $\mathrm{i}$ to sentrale semiotiske praksiser. Den første er designen av abc-apper. Den omfatter altså app-designernes kontekst, og resulterer i produksjonen av den semiotiske artefakten abc-app. Denne artefakten kan i neste omgang anvendes i ulike bruks-praksiser, det være seg i hjemmet, i barnehagen eller på andre arenaer, og bidra til å forme og strukturere de sosiale praksisene den der går inn i. Over tid vil de sosiale praksisene påvirke hverandre, for eksempel ved at endringer i bruksmåter fører til app-oppdateringer.

App-produsentenes praksiser er regulert av ulike normer og diskurser, deriblant designkonvensjoner samt kunnskaper og forestillinger om de praksisene som 
teknologien er tenkt brukt i (jf. Zhao, Djonov \& van Leeuwen, 2014). Gjennom sine mer eller mindre bevisste designvalg, befester og forsterker app-produsentene visse aspekter ved literacy, og toner ned andre. Ved å analysere appene som semiotiske artefakter, kan man slik identifisere sentrale trekk ved aktørenes literacy-teorier.

Literacy-forskninga har viet mye oppmerksomhet til abc-ressurser i bruk (jf. semiotisk praksis 2 i skolen, for eksempel digitale abc-verk (se f.eks Flatøy, 2010; Runestad, 2015) og nettbrett-lesespill i begynneropplæringa (McTigue \& Uppstad, 2019). Det har vært langt mindre oppmerksomhet om den digitale designen av abc-ressurser (semiotisk praksis 1). Den teoretiske forankringa i sosiokulturell literacy-forskning i kombinasjon med sosialsemiotiske perspektiver på multimodalitet og teknologi, gjør det mulig å belyse hvordan appene som semiotiske og teknologiske artefakter er innskrevet med visse kulturelle ideer og idealer, i dette tilfellet literacy-teorier, og hvordan de bidrar til å forme og strukturere appene og bruken av disse.

\section{Material og tilnærming}

\section{Utvalg og utvalgskriterier}

Det empiriske materialet består av ni apper, vist i tabell 1. Utvalgskriteriene har vært at appene 1) er norskspråklige iPad-apper 2) for barn i førskolealder 3) som inngår i sjangeren abc-apper 4) som er produsert av kommersielle aktører.

Det første kriteriet avgrenser materialet til apper som bruker det norske alfabetet (inkl. æ, ø, å), norsk tale samt norskspråklig Appstore-presentasjon. Apper med Appstore-presentasjon som er automatisk oversatt, er ikke tatt med. Kun iPad-apper er undersøkt. Erfaringsvis rommer Appstore flere apper enn Googleplay og andre aktører, men det kan likevel tenkes at relevante apper ikke har blitt vurdert.

Alle appene i utvalget oppgir førskolealder som målgruppe i Appstore, enten i alderskategorien eller i presentasjonsteksten. Målgruppa er for de fleste «4+». Noen er spesifisert til for eksempel «4+, rettet mot aldersgruppen 0-5 år». Noen har oppgitt «4+, rettet mot aldersgruppen 6-8», men egenbeskrivelse angir for disse også førskolebarn, jf. tabell 1.

Tabell 1. Oversikt over appene i studien. Appstore-informasjon sist lest 25.6.2019.

\begin{tabular}{|c|c|c|c|c|c|}
\hline Navn på app & Produsent & $\begin{array}{l}\text { Opp- } \\
\text { rinnelse }\end{array}$ & Utvalg & $\begin{array}{l}\text { Alderskategori } \\
\text { i Appstore }\end{array}$ & $\begin{array}{l}\text { Aldersangivelse i } \\
\text { presentasjonsteksten } \\
\text { i Appstore }\end{array}$ \\
\hline $\begin{array}{l}\text { Alfabetet på } \\
\text { Norsk }\end{array}$ & Tommy Fossli & Norsk & & $\begin{array}{l}4+\text {, rettet mot } \\
\text { aldersgruppen } 0-5\end{array}$ & $\begin{array}{l}\text { «Passer for barn fra } \\
2-8 \text { år» }\end{array}$ \\
\hline $\begin{array}{l}\text { Alf-laer } \\
\text { bokstaver }\end{array}$ & Nalycan & Norsk & $\begin{array}{l}\text { del av } \\
\text { app-pakke }\end{array}$ & $\begin{array}{l}4+\text {, rettet mot } \\
\text { aldersgruppen } 6-8\end{array}$ & $\begin{array}{l}\text { «passer for barn mellom } \\
4-10 \text { år» }\end{array}$ \\
\hline Bogga alfabet & Boggatap & Norsk & $\begin{array}{l}\text { del av } \\
\text { app-pakke }\end{array}$ & $\begin{array}{l}4+\text {, rettet mot } \\
\text { aldersgruppen } 0-6\end{array}$ & $\begin{array}{l}\text { "passer barn fra } 2 \text { år og } \\
\text { oppover» }\end{array}$ \\
\hline
\end{tabular}




\begin{tabular}{|c|c|c|c|c|c|}
\hline Navn på app & Produsent & $\begin{array}{l}\text { Opp- } \\
\text { rinnelse }\end{array}$ & Utvalg & $\begin{array}{l}\text { Alderskategori } \\
\text { i Appstore }\end{array}$ & $\begin{array}{l}\text { Aldersangivelse i } \\
\text { presentasjonsteksten } \\
\text { i Appstore }\end{array}$ \\
\hline Bokstavkongen & $\begin{array}{l}\text { Alphabet King } \\
\text { Leap Learning }\end{array}$ & Norsk & & $4+$ & \\
\hline $\begin{array}{l}\text { Knekk } \\
\text { Lesekoden }\end{array}$ & Minitutor & Norsk & & $4+$ & $\begin{array}{l}\text { «Målgruppe: 4-10 } \\
\text { år (de som ikke kan } \\
\text { lese, eller som har } \\
\text { lesevansker» }\end{array}$ \\
\hline $\begin{array}{l}\text { Lek } A B C, \\
\text { Albert Åberg }\end{array}$ & Gro Play & Svensk & & $\begin{array}{l}4+\text {, rettet mot } \\
\text { aldersgruppen } 6-8\end{array}$ & $\begin{array}{l}\text { «Barn vil leke og lære } \\
\text { med appen på sine } \\
\text { egne premisser og i eget } \\
\text { tempo, i barnehagen, på } \\
\text { skolen eller hjemme» }\end{array}$ \\
\hline $\begin{array}{l}\text { Lolas } \\
\text { Alfabettog }\end{array}$ & $\begin{array}{l}\text { Lola Panda / } \\
\text { BeiZ }\end{array}$ & Finsk & $\begin{array}{l}\text { del av app-pakke. } \\
\text { Nivået «lett» }\end{array}$ & $\begin{array}{l}4+\text {, rettet mot } \\
\text { aldersgruppen } 0-5\end{array}$ & $\begin{array}{l}\text { «spesielt utviklet for } \\
\text { 3-7-åringer» }\end{array}$ \\
\hline Ordlek XL & GI Labs & Norsk & & $\begin{array}{l}4+\text {, rettet mot } \\
\text { aldersgruppen } 6-8\end{array}$ & $\begin{array}{l}\text { «laget for aldersgruppen } \\
4-7 \text { år» }\end{array}$ \\
\hline $\begin{array}{l}\text { Sofie - Syng, } \\
\text { lek og ler }\end{array}$ & $\begin{array}{l}\text { Egmont Kids } \\
\text { Media Digital }\end{array}$ & Dansk & $\begin{array}{l}\text { Kun alfabetet - } \\
\text { delen av appen }\end{array}$ & $\begin{array}{l}4+\text {, rettet mot } \\
\text { aldersgruppen } 0-5\end{array}$ & «for de minste» \\
\hline
\end{tabular}

Sjangeren «abc-app» er det tredje kriteriet. Dette er en ganske åpen sjanger (jf. innledende beskrivelse), men avgrenser empirien fra tilgrensende sjangrer, deriblant bildebokapper (jf. Tønnessen, 2015), for eksempel Se og si, og fra aktivitetsapper med bredere læringsinteresse, så som SirMania og Puppet Pals. Også den populære appen Poio er utelatt av sjangermessige grunner, noe som er mer diskutabelt. Poio tilbyr abc-aktiviteter som gjør at barna kan oppdage bokstavenes former og lyder, og kan innholdsmessig sies å være en abc-app. Poios rike og omfattende spillunivers, som det tar mange timer å utforske, i motsetning til de inkluderte appenes små og oversiktlige univers, giør imidlertid at den har en annen form og struktur enn de andre. Jeg har derfor funnet det vanskelig å innlemme Poio i abc-sjangeren i denne undersøkelsen.

Det fjerde kriteriet, "kommersielle aktører», innebærer i denne konteksten en avgrensning mot de store skolebokforlagenes apper tilknytta leseopplæringsverk (f.eks. Aschehoug forlags Zeppelin) samt apper som er utvikla av forskningsinstitusjoner (Lesesenterets $P a ̊$ sporet $A B C$ ). Det er fordi deres apper er retta mot opplærings-institusjoner, har skoleelever som hovedmålgruppe, og kan ventes å ha institusionalisert tilgang til fagkunnskap. Skolebokforlag er samtidig kommersielle aktører, så betegnelsen er diskutabel. Ingen apper har imidlertid gjort anvendelsen av dette kriteriet krevende, for eksempel er det ingen apper fra «småforlag» som har blitt ekskludert.

Enkelte apper, deriblant Bogga og Lola, kommer i pakker/serier. Jeg har valgt å ta med én app fra hver produsent for å unngå at helhetsbildet blir for sterkt preget av 
enkeltaktører. Jeg har da valgt den appen som var lista først i Appstore. Lola-appen tilbyr aktiviteter i tre vanskenivåer, og siden dette gjelder førskolebarn har jeg kun sett på nivået «lett».

Jeg har funnet fram til appene i Appstore ved hjelp av søkeord som «alfabet», «abc», «bokstaver» og «lær å lese». Jeg har også fulgt dette feltet over tid, og fått mange uformelle innspill fra studenter og kollegaer i barnehagelærerutdanninga. Det kan likevel tenkes at det finnes apper som fyller utvalgskriteriene som jeg ikke har fanget opp. De ni appene i materialet dekker imidlertid det som i skrivende stund utgjør hele tilbudet av abc-apper $i$ henhold til utvalgskriteriene og avgrensningene som er redegjort for ovenfor.

\section{Analysestrategi}

Appene har blitt undersøkt ved at jeg «spilt» hver app mange ganger, og registrert hva slags literacy-erfaringer den tilbyr. Jeg har sett etter mønstre i disse, og identifisert sju typer av aktiviteter. Analysen er strukturert etter disse sju.

Jeg beskriver for hver av disse sju først hvordan den aktuelle typen literacy-aktivitet er organisert, og gir noen eksempler fra utvalget. Deretter løfter jeg fram ett eller flere kvalitetstrekk som jeg har identifisert gjennom arbeidet med appene i dialog med faglitteratur.

Kvalitetstrekkene varierer i omfang og form mellom de ulike literacy-aktivitetene. Kvalitet er et mangfoldig fenomen, og jeg har derfor ikke etterstreba en enhetlig form. De identifiserte kvalitetstrekkene er ikke ment å være fullstendige dekkende, men en utpeking av særlig sentrale kvalitetstrekk med basis i dette app-korpuset. Andre forskere og andre abc-ressurser vil altså kunne utpeke andre kvalitetstrekk som mer sentrale. Hensikten med å peke ut kvalitetstrekk er ikke å lukke rommet for videre kvalitetsdiskusjoner, men derimot å eksplisittere, åpne opp og forsterke dem.

\section{Analyse: literacy-aktiviteter og kvalitetstrekk}

Analysen er strukturert etter de sju typene av literacy-aktiviteter som jeg har funnet at abc-appene består av, nedenfor lista fra mest til minst utbredt:

1. Bokstav-lyd-kobling

2. Bokstavutforming

3. Staving

4. Hukommelsesaktiviteter

5. Tekstproduksjon

6. Lesing

7. Sang

Tabell 2 nedenfor gir en oversikt over hvilke literacy-aktiviteter de ulike appene tilbyr.

Appene er i stor grad bygd opp rundt aktiviteter som man ganske enkelt kan identifisere som å tilhøre én kategori. Aktiviteten bokstav-lyd-kopling overlapper imidlertid ofte med andre aktiviteter, særlig staving og bokstavutforming, ved at bokstavutforminga/stavinga ledsages av uttale av lyden til eller navnet på bokstaven. I tabell $2 \mathrm{er}$ 


\section{G. Kvåle}

Tabell 2. Oversikt over literacy-aktiviteter i det empiriske utvalget. Lysegrå farge markerer at aktiviteten (bokstav-lyd-kobling) er underordnet en annen aktivitet.

\begin{tabular}{|l|l|l|l|l|l|l|l|l|l|}
\hline & $\begin{array}{l}\text { Alfabetet } \\
\text { på Nork }\end{array}$ & $\begin{array}{l}\text { Alf - lær } \\
\text { bokstaver }\end{array}$ & $\begin{array}{l}\text { Bogga } \\
\text { alfabet }\end{array}$ & $\begin{array}{l}\text { Bokstav- } \\
\text { kongen }\end{array}$ & $\begin{array}{l}\text { Knekk } \\
\text { Lese- } \\
\text { koden }\end{array}$ & $\begin{array}{l}\text { Lek } \\
\text { ABC - }-\begin{array}{l}\text { Lolas } \\
\text { Albert } \\
\text { alfabettog }\end{array}\end{array}$ & $\begin{array}{l}\text { Ordlek } \\
\text { XL }\end{array}$ & $\begin{array}{l}\text { Sofie - } \\
\text { Syng, } \\
\text { lek og } \\
\text { lær }\end{array}$ \\
\hline $\begin{array}{l}\text { Bokstav-lyd- } \\
\text { kobling }\end{array}$ & & & & & & & & & \\
\hline $\begin{array}{l}\text { Bokstav- } \\
\text { utforming }\end{array}$ & & & & & & & & & \\
\hline Staving & & & & & & & & & \\
\hline $\begin{array}{l}\text { Hukommelses- } \\
\text { aktiviteter }\end{array}$ & & & & & & & & & \\
\hline $\begin{array}{l}\text { Tekst- } \\
\text { produksion }\end{array}$ & & & & & & & & & \\
\hline Lesing & & & & & & & & & \\
\hline Sang & & & & & & & & & \\
\hline
\end{tabular}

aktiviteten kategorisert begge steder, men markert i lysegrå farge der den er underordnet en annen aktivitet.

Materialet er med få unntak dekket gjennom de sju nevnte aktivitetene. Det rommer likevel enkelte andre, herunder høytlesing (Bokstavkongen), fargelegging (Bokstavkongen), gjenkjenning av bokstavformer uten ledsagende lyd (Lolas Alfabettog) samt et spill uten klar kopling til literacy-aktiviteter (Alf-lar bokstaver). De nevnes her dels for å vise bredden i materialet, dels for å vise at de sju hovedaktivitetene gir en rimelig dekkende kategorisering av materialet.

\section{1) Bokstav-lyd-kopling}

Alle appene rommer som nevnt aktiviteter der barn skal kople mellom bokstav og lyd, enten som integrert del av andre aktivitet eller som en hovedaktivitet. Jeg konsentrerer meg her om sistnevnte.

I både Sofie og Alfabetet på Norsk er bokstav-lyd-kopling den bærende aktiviteten. De består av en alfabetisk organisert serie av bilder av objekter som forankrer framlyden i ordet til en bestemt bokstav. I begge appene brukes bokstavnavnet som auditivt uttrykk. I Sofie er for eksempel talesporet til bokstaven Bb «Denne bokstaven heter be», og fotografiet av en banan ledsages av den auditive formen «Banan begynner med be».

Knekk Lesekoden er organisert i to deler - «øv» og «spill». I «Bokstaver» under «Spill» er bokstav-lyd-kopling hovedaktiviteten. Sirkler med bokstaver vises da på skjermen, og lydsporet sier «Trykk på bokstaven du hører», etterfulgt av bokstavlyden, for eksempel «S» eller «k». 
En liknende form finnes også i Lolas alfabettog. På flere togstasjoner dukker det opp ruter med bokstaver (f.eks. B, F, J og T). En boble med en av bokstavene, for eksempel $\mathrm{F}$, daler ned, og barna skal trykke på den ruta som viser denne bokstaven, som så benevnes med sitt navn («eff»). På en annen togstasjon vises tegninger, for eksempel av ku, båt, tromme og en dronning, med det auditive spørsmålet «Hvilket ord begynner med bokstaven «de»?» Fasitsvaret er sistnevnte, som representeres lydlig som ««De» for dronning». Et annet eksempel er «Hvilket ord begynner med bokstaven «hå»?», der det riktige svaret er et bilde av en hval.

Som beskrivelsene så langt har vist, blir bokstavene i noen apper benevnt ved sitt navn (stavelsen «kå»), og i andre apper ved sin lyd (lukkelyden «k»). Tabell 3 gir en oversikt over appenes valg av bokstalyd/-navn. Den viser at bokstavlyd brukes i Alfler bokstaver, Bokstavkongen, Knekk Lesekoden og Ordlek XL, mens bokstavnavn brukes i Alfabetet på Norsk, Albert Åberg, Lolas Alfabettog og i Sofie. I Bogga Alfabet kan man velge mellom bokstavlyd og bokstavnavn.

Videre viser tabell 3 valg av forankringsord. Ikke alle apper har dette. Kolonnen ytterst til høyre gir eksempler på forankringsord i tre kategorier: Forankringsord med lydrett (LR), potensielt lydstridig (PLS) og lydstridig (LS) framlyd. Potensielt lydstridige framlyder handler om mangfoldet i norske talemål, for eksempel begynner "ost» med en o-lyd for mange barn, mens det hos noen starter med en å-lyd («åst»)

Tabell 3. Oversikt over appenes valg av bokstavlyd versus bokstavnavn samt bruk av forankringsord, kategorisert etter lydrett, potensielt lydrett og lydstridig framlyd.

\begin{tabular}{|c|c|c|c|c|}
\hline Navn på app & Bokstav-lyd & Bokstav-navn & Kommentar & Forankringsord \\
\hline \multirow[t]{3}{*}{ Alfabetet på Norsk } & & & & $\begin{array}{l}\text { LR: ape, dinosaur, elefant, ku, } \\
\text { pingvin }\end{array}$ \\
\hline & & & & PLS: orm, ugle \\
\hline & & & & $\begin{array}{l}\text { LS: giraff, skilpadde, yoghurt, } \\
\text { øyenstikker }\end{array}$ \\
\hline \multicolumn{5}{|l|}{ Alf-ler bokstaver } \\
\hline Bogga alfabet & & & $\begin{array}{l}\text { Kan velge mellom } \\
\text { bokstavlyd og -navn }\end{array}$ & \\
\hline \multicolumn{5}{|l|}{ Bokstavkongen } \\
\hline \multicolumn{5}{|l|}{ Knekk Lesekoden } \\
\hline \multirow[t]{3}{*}{$\begin{array}{l}\text { Lek } A B C, \\
\text { Albert Åberg }\end{array}$} & & & \multirow{3}{*}{$\begin{array}{l}\text { "Synger» en serie } \\
\text { bokstavnavn som } \\
\text { en melodi } \\
\text { ("kå-kå-kå-kå») }\end{array}$} & $\begin{array}{l}\text { LR: ape, bok, katt, ved, hatt, sag, } \\
\text { ufo, oliven }\end{array}$ \\
\hline & & & & PLS: ugle \\
\hline & & & & LS: Skybert \\
\hline \multirow[t]{3}{*}{ Lolas Alfabettog } & & & & LR: ku, gorilla, bøffel, tromme \\
\hline & & & & PLS: ulv, ugle \\
\hline & & & & LS: geit, hval \\
\hline \multicolumn{5}{|l|}{ Ordlek XL } \\
\hline \multirow{3}{*}{$\begin{array}{l}\text { Sofie - Syng, } \\
\text { lek og leer }\end{array}$} & & & & LR: banan, gris, iglo, nøkkel, øre \\
\hline & & & & PLS: ost, ugle \\
\hline & & & & LS: yatzy \\
\hline
\end{tabular}




\section{G. Kvåle}

\section{Kvalitetstrekk 1: Bokstavlyd eller bokstavnavn}

I praktisk lese- og skriveopplæring har bruken av bokstavlyd, og ikke bokstavnavn, lenge vært det anbefalte valget, særlig med utgangspunkt i kognitive perspektiver (jf. tidligere seksjon). Det gjør appers valg mellom bokstavlyd og -navn til et viktig kvalitetstrekk for denne aktivitetstypen, for eksempel om bokstavforma G/g blir auditivt representert som stavelsen «Ge» eller lukkelyden «g». Apper som bruker bokstavlyd kan ukontroversielt vurderes å holde høyere kvalitet enn de som bruker bokstavnavn når det gjelder å kople bokstavform og lyd.

\section{Kvalitetstrekk 2: Lydrette eller lydstridige forankringsord}

Nærvær eller fravær av forankringsord er ikke i seg selv en indikator på kvalitet. Derimot kan kvalitet knyttes til hvorvidt det i appen er valgt forankringsord der framlyden har en uttale som korresponderer med bokstavlyden, jf. det problematiske eksemplet "geit for g» i Vollans artikkeltittel (Vollan, 2010a). Valg av ikke-lydrette forankringsord for bokstaver som enkelt kan representeres med lydrette forankringsord, kan ganske ukontroversielt vurderes som å senke kvaliteten. Noen bokstaver er det riktignok vanskeligere å finne lydrette forankringsord for, eksempelvis Y samt bokstavene som på norsk ikke har et korresponderende fonem (C, X, Q, Z og W).

\section{Kvalitetstrekk 3: Forankringsbildenes tolkingsstøtte}

Vollan (2010ab) peker på at de kommersielle abc-ressursene i en del tilfeller fikk svekka kvalitet fordi bildet ga lite kontekstuell støtte, samtidig som at aktiviteten hadde en bestemt verbal fasit. Dette problemet synes noe mindre framtredende $\mathrm{i}$ app-materialet. Det er likevel flere eksempler på at dette bidrar til å senke kvaliteten. En tegning av en kjolekledd kvinneskikkelse kan aktualisere mange ordformer dame, prinsesse, kjole, ballkjole - men i Lolas Alfabettog er den eneste akseptable verbaliseringa dronning, som nevnt over. På den positive siden kan Ordlek XLs valg av mer entydige, men samtidig estetisk tiltalende fotografier sies å gi god støtte. Tolkningsstøtten til forankringsbildene er følgelig et trekk som kan bidra til både å heve eller senke kvaliteten på en abc-app.

\section{2) Bokstavutforming}

Bokstavutforming finnes i fem apper: Alf, Bogga, Bokstavkongen, Knekk Lesekoden og Albert Aberg, i flere av dem som en hovedaktivitet.

Aktiviteten er organisert på ulike måter. For det første kan det skilles mellom hvorvidt bokstavutforminga tar form av sporing av forhåndsdefinerte former eller som fri utforming. Sistnevnte finner man kun hos Bokstavkongen, der barna skal utforme en bokstav, f.eks. K, på linjer ved hjelp av fingeren. Linjene som da skapes, følger barnets bevegelser. Sporing er imidlertid mest utbredt, og innebærer at barna med fingeren skal følge eller fylle ut bokstavformer. Da blir resultatet alltid en perfekt form.

Noen apper, bl.a. Knekk Lesekoden, krever et bestemt bevegelsesmønster for at formen blir akseptert, mens andre, for eksempel Bogga Alfabet, tillater utfylling slik 
barnet selv måtte ønske - enten å følge den indikerte standardretninga, berøre hele flaten, eller å «prikke» den fram. Albert Åberg-appen gir en særegen leken og estetisert respons på bokstavutforminga, ved at linjene man tegner opp omformes til for eksempel garntråder, perlekjeder eller rør i en elegant filmatisk scene, ledsaget av reallyd.

\section{Kvalitetstrekk 4: Bokstavutformingas bevegelsesmønster}

I flere apper er sporingsbevegelsen indikert gjennom piler, og derigjennom fremstilt som å angi en korrekt bevegelse. Teknologien kan også sette denne bevegelsesbanen som den eneste akseptable responsen. Dermed etableres korrekt bevegelsesmønster som en relevant kvalitetsindikator.

I mange apper er dette gjennomført på en uproblematisk måte, men i noen apper bryter utforminga av enkelte bokstaver med anbefalt praksis. Et eksempel gjelder den diagonale linja i bokstaven $\varnothing$ i Alf-ler bokstaver. Appen krever at man starter nede til venstre og sporer linja diagonalt oppover mot høyre, og kun denne forma aksepteres. I faglitteraturen er imidlertid også den motsatte retninga anbefalt (Hekneby, 2011, s. 151). Den omvendte bevegelsen (å starte den diagonale linja øverst og trekke den nedover) er etter hva jeg forstår den forma som tradisjonelt har vært vanligst.

\section{Kvalitetstrekk 5: Perfekt bokstavutforming eller barnets bokstavutforming}

Aktiviteten varierer som nevnt med henblikk på om bokstavformen er en ferdigutfylt form, eller om resultat reflekterer brukerens irregulære håndbevegelser. Kvalitetsforskjellene mellom disse er mer kontekstsensitive. Dersom barnets frie utforsking anses som det viktigste i bruks-praksisen, vil barnets form kunne anses som et kvalitativt bedre valg. Dersom etablering av sikker bokstavkunnskap er det viktigste, vil ferdigutfylt form kunne vurderes som kvalitativt bedre. Selv om man vanskelig kan gi en kontekstuavhengig vurdering av dette trekket, kan valget like fullt ha kvalitetsmessige konsekvenser.

\section{3) Staving}

Staving viser til aktiviteter der barna skal sette bokstaver sammen til en rekkefølge slik at de former bestemte ord. Staving er her altså ikke fri skriftlig tekstproduksjon, men en ordning av bokstaver i ortografisk riktig rekkefølge. Dette er en sentral literacyaktivitet i tre apper: Ordlek XL, Lolas Alfabettog og Albert Åberg. Den utfoldes imidlertid på ulike måter.

I Ordlek $X L$ er staving den eneste aktiviteten. Der vises et fotografi av et objekt, for eksempel en mus, samt usorterte brikker med bokstavene i ordet. Brikkene skal så innplasseres på riktig sted i en serie av tomme felt. Ved berøring av en brikke angis bokstavlyden auditivt, og når alle er plassert på rekka, leses alle lydene opp, samt det riktig stava ordet. Staves det feil, gir appen beskjed om det og man får stave på nytt. Det synes i stor grad å være valgt ord som er relevante for norske førskolebarn. Orda er som oftest sentrale ord i norske barns vokabular som lydrette og ganske korte, men enkelte frekvente lydstridige ord brukes, for eksempel øye, blad og tau. 


\section{G. Kvåle}

Aktivitetene i Lolas Alfabettog omfatter også staving. Noen ord er ganske korte og som oftest lydrette ord, for eksempel ku og ulv. Det er også mange eksempler på lydstridige ord, for eksempel geit, jakke, gorilla og bøffel. Inntrykket etter gjentatt spilling er at det er flere lydstridige enn lydrette ord i denne Lola-appen.

I Albert Aberg inngår stavinga i det Appstore-beskrivelsen kaller en "ordmaskin». Barna kan der velge mellom orda de har fått gjennom bokstavutforminga, for eksempel «bjørn» eller «Skybert». De skal så staves ved at bokstavene framtrer på skjermen som løse «brikker» som skal plasseres i riktig rekkefølge. Når man berører en bokstavbrikke, synges en melodisk serie av bokstavnavn («kå-kå-kå-kå-kå»). Den samme aktiviteten dukker også opp i tekstproduksjonsaktiviteten (se nedenfor).

\section{Kvalitetstrekk 6:Vektlegginga av korrekt staving}

I faglitteraturen er det stor enighet om at det for barn i førskolealder generelt $i k k e$ er viktig å kunne stave ord korrekt (jf. tidligere avsnitt). Selve nærværet av denne aktiviteten kan således problematiseres med tanke på kvalitet. For svært mange førskolebarn er rettskriving en aktivitet som i mindre eller liten grad støtter literacy-utviklinga deres på de mest relevante utviklingsområdene, selv om det for en del førskolebarn vil kunne være sosialt og kognitivt relevant.

\section{Kvalitetstrekk 7: Staving av lydrette eller lydstridige ord}

Det er som vist flere apper som krever korrekt staving av ord, både lydrette og lydstridige. Produsentenes valg mellom lydrette og lydstridige ord er også en kvalitetsindikator. For førskolebarn generelt vil staving av lydrette ord som tommelfingerregel ha høyere kvalitet for deres literacy-utvikling enn bruk av lydstridige ord, siden mestring av ortografiske regler ikke anses som vesentlig for barn under skolealder (jf. tidligere avsnitt).

Dette valget bør samtidig ses i sammenheng med ordenes relevans for barnas livsverden; hvorvidt ordene refererer til saksforhold som er viktige for barn og dermed kan være mye brukt. For eksempel kan bruken av ordet øye i Ordlek XL med utgangspunkt i dette anses som å gi kvalitativt bedre støtte enn staving av ordet bøffel i Lolas Alfabettog.

\section{4) Hukommelsesaktiviteter}

Flere apper - Bogga Alfabet, Bokstavkongen og Lolas Alfabettog-rommer hukommelsesaktiviteter i form av memory-spill. En serie av kort vises da med spill-siden ned. Barna må klikke på kortene for å snu dem, og memorere de ulike kortenes plassering for å kople dem sammen til par. Også Alf - lar bokstaver har en hukommelsesaktivitet. Man ser der alle bokstavene i alfabetet på skjermen, i alfabetisk rekkefølge. Appen uttaler en og en bokstavlyd i helt tilfeldig rekkefølge, samtidig med at den «blinker» $\mathrm{i}$ bokstavoversikten. Man skal så gjenta rekkefølgen, med stadig økende antall bokstaver. 


\section{Kvalitetstrekk 8: Meningsfull moro}

Det viktigste kvalitetstrekket ved denne aktiviteten handler om i hvilken grad den tilbyr meningsfull moro. Presiseringa «moro» knyttes her til den analoge varianten av memory-spill, som mange barn og voksne kan ha moro av å delta i, mens presiseringa «meningsfull» knytter seg til aktivitetens forståelighet. Sistnevnte gir grunn til å problematisere hukommelsesaktiviteten i appen Alf-ler bokstaver. Det å huske tilfeldige serier av bokstaver som ikke kan koples sammen til ord, kan vanskelig sies å gi svært relevant kognitiv støtte eller forståelighet. Siden bokstavenes rekkefølge ikke danner ord, blir det en bokstavelig talt en meningsløs aktivitet.

\section{5) Tekstproduksjon}

Noen app-aktiviteter rommer fri tekstproduksjon: å skape verbale, visuelle og/eller multimodale tekster. Tekstproduksjonsaktiviteter finnes i Bogga Alfabet, Bokstavkongen og Albert Åberg, men er realisert på ulike måter.

Bogga-appen tilrettelegger for verbal skriving ved at barna kan sette sammen bokstavformer i selvvalgt rekkefølge, visuelt iscenesatt som kjøleskapsmagneter. Albert Åberg-appen tilrettelegger for visuell tekstkomposisjon i form av lek med visuelle figurer i et slags dokketeater. Bokstavkongen tilrettelegger for multimodal tekstproduksjon ved at barna kan skape bildebokoppslag ved å kombinere bokstaver og visuelle bilder. Man kan velge mellom ulike bakgrunner, objekter og karakterer fra eventyruniverset $\mathrm{i}$ appen, og sette inn små og store bokstaver. Alle elementene kan justeres opp og ned i størrelse, og plasseres hvor man måtte ønske på flaten.

\section{Kvalitetstrekk 9:Vektlegging av fri tekstproduksjon}

I faglitteratur om førskolebarns literacy blir gjerne nettopp den frie tekstproduksjonen framheva. Apper som tilrettelegger for lekende og utforskende tekstskaping kan som følge av dette sies å ha et større kvalitetspotensial enn apper som ikke giør det, såframt aktiviteten er organisert på en relevant måte, jf. neste punkt.

\section{Kvalitetstrekk 10: Tekstproduksjonens utfoldelsesrom}

Dette kvalitetstrekket handler om hvor rikt materialet er når det gjelder utforskning og lek, og hvorvidt den lekende utforskninga blir respektert. Et positivt eksempel er hvordan Bogga Alfabet legger til rette for at bokstavlek med digitale kjøleskapsmagneter. De kan plassere bokstavene hvor de vil, og sette dem sammen til rekker som danner faktiske ord så vel som nonsensord. Et annet er hvordan Bokstavkongen er designet slik at barna lekent kan skape fortellinger ved å velge mellom ulike bokstaver og figurer som kan settes inn, tas ut, flyttes rundt og endres i størrelse.

Kvalitetstrekket gir grunn til å problematisere Albert Åberg-appens sammenkopling av visuell dokketeater-lek og staving. Hvis man i dokketeateret peker med «tryllestaven» mot en figur, f.eks. Skybert, får man opp alle bokstavene i figurens navn og skal stave den riktig, her «skybert». Den kreative visuelle tekstproduksjonen blir på 


\section{G. Kvåle}

den måten innplassert i og underordna en riktig/feil-innramming som begrenser den lekende utforskninga.

\section{6) Lesing}

Lesing betegner app-aktiviteter som krever at barna utfører en lesehandling overfor bokstaverte ord, det være seg gjetter, lekeleser, helordsleser, leser fonologisk eller leser ortografisk/automatisert. Man finner dette i Lolas alfabettog og Knekk Lesekoden.

Toget til Lola stopper på flere aktivitet-stasjoner der appen spør «Hva er dette?» Visuelt vises da en tegning av et objekt, for eksempel en båt, samt noen bokser med ord, for eksempel «båt», «kamel», «sebra». Barna må på den måten utføre en lesehandling for å kunne klikke på det riktige ordet.

I Knekk lesekoden er det to aktiviteter som krever en lesehandling. I den ene dreier det seg om høyfrekvente, lydstridige ord. I lydsporet bes barnet om å trykke på ordet de hører, og sier så det aktuelle ordet, for eksempel «og». Visuelt vises et lite antall bokser med ulike ord, og barnet skal finne den riktige. I den andre aktiviteten dreier det seg om stavelser, i appen benevnt «tulleord». Appen gir da verbalt en instruksjon om å trykke på lyden du hører, hvorpå den aktuelle lydkombinasjonen uttales, for eksempel "vø». På flaten står flere andre lydkombinasjoner, for eksempel «ky», "ka» og «sæ».

\section{Kvalitetstrekk 11: Lesing av lydrette eller lydstridige ord}

Valget mellom lydrette framfor lydstridige ord et ganske entydig kvalitetshevende trekk for førskolebarn (jf. trekk 7). Med utgangspunkt i materialet kan man sondere mellom intenderte og tilfeldige valg, for i Knekk Lesekoden er det bevisst valgt å benytte lydstridige ord i enkelte deler av appen, mens det i Lola-appen synes tilfeldig.

\section{Kvalitetstrekk 12: Meningsfulle lesehandlinger}

Dette kvalitetskriteriet handler om lesehandlingas mål; om hva som synes å være den ønska meningshendelsen. Et vanlig og uproblematisk mål er at lesinga skal føre til at barnet får tak på meningsinnholdet i et ord. Dette kriteriet er imidlertid aktualisert av Knekk Lesekodens "tulleord» dvs. vokal-konsonant-kombinasjoner som $i k k e$ har dette målet. Lydsekvensene som skal leses er nettopp sekvenser av lyder (f.eks. «vø»), men de kan ikke knyttes til et meningsinnhold. Når lesehandlinga helt frakoples mening, vil aktiviteten i mindre grad tilby barna vesentlige literacy-erfaringer. Aktiviteten kan riktignok ha et kognitivt potensial, men siden lydsekvensene som brukes som oftest ikke sammenfaller med verken frekvente morfemer eller stavelser i norsk, svekkes også dette.

\section{7) Sang}

To apper rommer literacy-aktiviteter i form av abc-sanger. I Bokstavkongen er det en egenprodusent pop-aktig låt. I Sofie er det en velkjent abc-sang der bokstavnavna 
avsynges til melodien "Twinkle, twinkle little star», mens man visuelt ser alfabetet der den aktuelle bokstaven markeres når den avsynges.

\section{Kvalitetstrekk 13: Språklig og musikalsk glede}

Sang-aktiviteter inviterer til glede over språkets musikalske egenskaper. De viktigste kvalitetstrekkene handler derfor om hvorvidt sangene kan gi språklig og musikalsk glede, noe begge de to appene må sies å kunne. I materialet er det ikke tatt valg som gir grunnlag for identifisering av mer spesifikke kvalitetstrekk.

\section{Oppsummering}

Analysen har identifisert at det er sju aktiviteter som er dominerende i kommersielle aktørers abc-apper for norskspråklige førskolebarn. Analysen har videre identifisert til sammen tretten kvalitetstrekk i tilknytning til disse. Tabell 4 oppsummerer disse. I neste del vil jeg diskutere og reflektere over hva disse aktivitetene og kvalitetstrekkene viser om de kommersielle produsentene literacy-teorier.

Tabell 4. Oversikt over vanlige literacy-aktiviteter i abc-apper og tilhørende kvalitetstrekk.

\begin{tabular}{ll}
\hline Literacy-aktivitet & Kvalitetstrekk \\
\hline Bokstav-lyd-kopling & 1. Bokstavlyd eller bokstavnavn \\
& 2. Lydrette eller lydstridige forankringsord \\
& 3. Forankringsbildenes tolkingsstøtte \\
Bokstavutforming & 4. Bokstavutformingas bevegelsesmønster \\
5taving & 5. Perfekt bolkstavutforming eller barnets bokstavutforming \\
& 6. Vektlegginga av korrekt staving \\
Hukommelsesaktiviteter & 7. Staving av lydrette eller lydstridige ord \\
Tekstproduksjon & 8. Meningsfull moro \\
Lesing & 9. Vektlegging av fri tekstproduksjon \\
10. Tekstproduksionens utfoldelsesrom \\
Sang
\end{tabular}

\section{Diskusjon: literacy-teorier og kvalitet i kommersielle abc-apper}

Abc-apper er semiotiske artefakter som reflekterer interessene til de semiotiske praksisene de har blitt til i (jf. Zhao, Djonov \& van Leeuwen, 2014). Appene er altså prega av de normene, kunnskapene og designprinsippene som er virksomme i de sosiale kontekstene som produsentene er del av og mer eller mindre bevisst henter inspirasjon fra. I app-produksjonen gir utviklerne preferanse til visse sett av muligheter, og toner ned, eller ikke tenker over, andre muligheter. Appene er på den måten innskrevet med visse ideer og idealer, deriblant literacy-teorier. Hva viser så 


\section{G. Kvåle}

app-analysen om literacy-teoriene til de kommersielle aktørene, og hva har det å si for appenes potensial og kvalitet?

Analysen har vist at det er sju aktiviteter som går igjen. Selv om det står ulike aktører bak appene, er aktivitetsrepertoaret altså forholdsvis begrensa. Repertoaret kan videre karakteriseres som forholdsvis tradisjonelt og skole-aktig, for eksempel ved at barna skal utforme bokstaver for hånd, lese og stave ord riktig, huske ord og bilder og synge bokstavsanger. En app-analyse kan ikke vise hvor aktørene henter sin inspirasjon fra, men det synes nærliggende å tenke at utvalget blant anna er ramma inne av app-utviklerenes minner om egen skolegang, deres forestillinger om hva som er «typiske» skoleaktiviteter, eller deres forestillinger om hva app-kjøperne anser som ønskelige aktiviteter.

Aktivitetstypene gir også indikasjoner på hva som ikke er sentralt i aktørenes literacy-teorier. Abc-apper går inn i en historisk linje av kommersielle abc-ressurser, der ikke minst abc-boka har vært sentral. Den danske litteraturforskeren Anna Skyggebjerg (2018) er opptatt av abc-bokas særegne kombinasjon av didaktikk og estetikk (jf. tidligere avsnitt), både i visuelle og verbale modaliteter. Arbeid med språkets estetiske sider står som nevnt også sentralt i opplæringsinstitusjonenes arbeid med språklig bevissthet gjennom rim, regler og dikt. I abc-appene er det derimot få aktiviteter der språkets estetiske egenskaper er framtredende. Bortsett fra de to sangene (og Bokstavkongens høytlesningstekster), er det ingen bruk av dikt, rim og regler. Fraværet av rim og regler gjør også at språklig og tekstlig glede i form av tulling og tøysing med ord og lyder er lite framtredende. Literacy-potensialet i språkets estetiske dimensjon framstår dermed totalt sett som å være lite anerkjent i de fleste kommersielle aktørenes literacy-teorier.

Det kan også henge sammen med den faglige kunnskapsbasen til produsentene. På noen felt ser man at denne er begrenset, og at det får konsekvenser for appenes kvalitet som literacy-ressurser. Et tydelig eksempel er valget mellom bokstavnavn eller bokstavlyd, der flere apper får senka kvalitet som følge av at de anvender bokstavnavn og ikke -lyd. Dette valget er ikke teknologisk enklere eller billigere enn bokstavlyd, så det er rimelig å anta at produsentene ville valgt annerledes dersom de hadde hatt - eller skaffa seg - tilgang til noe mer kunnskap. Det samme kan man si om blant anna trekk 5 (korrekt bevegelsesmønster i bokstavutforming) og trekk 8 og 12 (lesing og skriving av lydrette og/eller lydstridige ord). Aktørenes begrensa kunnskapsbase er i tråd med funn fra Vollans undersøkelser (Vollan, 2010ab). Det kan indikere at utnyttelse av tilgjengelig fagkunnskap ikke spiller en sentral rolle i en del kommersielle aktørers produksjonspraksiser, verken når det gjelder papirbaserte eller digitale abc-ressurser.

Det er forholdsvis få apper som tilbyr fri tekstproduksjon (trekk 10), der barna kan utforske og leke med bokstaver og andre semiotiske ressurser og derigjennom oppdage tekstkulturens mulighetsrom og utvikle identitet som skriftspråkdeltakere. I faglitteratur om førskolebarns literacy-utvikling framheves derimot nettopp den utforskende skrivinga (jf. tidligere avsnitt). De tre appene som har tekstproduksjoner 
viser at det er mange muligheter for å designe utforskende og lekende tilnærminger. Totalt sett framstår dette aspektet ved literacy likevel som mindre sentralt hos app-produsentene.

Materialet viser derimot at et annet organiseringsprinsipp står svært sterkt i produsentenes literacy-teorier: Korrekt/ukorrekt. Mange aktiviteter er organisert etter dette prinsippet, for eksempel når barna skal utføre korrekte lesehandlinger, stave lydrette så vel som lydstridige ord korrekt, og utforme bokstaver på korrekt måte. Den sterke posisjonen til korrekt/ukorrekt viser seg også ved at multimodale belønninger for korrekt gjennomført handling er mye brukt. Det framgår ikke direkte av analysen, men i app-materialet florerer auditive applauser, stjernedryss, heia-rop, visuelle framdriftsindikatorer, trofeer, mynter, poeng og skriftlige/og eller muntlige tilbakemeldinger («Supert!», «Så flink du er!»). De mange multimodale belønningene bidrar til å konfigurere relasjonen mellom barn, literacy og teknologi på måter som giør at det utforskende og lekende blir tona ned, mens det observerbare og belønnbare blir framheva.

En app-analyse kan ikke avdekke årsakene til at korrekt/ukorrekt og multimodale belønninger står så sterkt i de fleste kommersielle aktørenes literacy-teorier; det vil kreve andre metodiske tilnærminger. Det er imidlertid rimelig å forstå det som å reflektere en app-produksjonspraksis i en kulturell kontekst der språk, især skriftspråk, er innvevd i sterke normative idealer om korrekthet - om at det riktige også er det viktige. Ved at design-praksisens riktighetsidealer er innskrevet $i$ appene, blir de i neste omgang videreført til brukspraksisene, og de kan dermed komme til å bli ytterligere befesta og forsterka i den kulturelle konteksten.

Korrekt-ukorrekt-logikken samsvarer også med digitale teknologiers fundamentale input-output-logikk. Dimensjonen er også mye brukt i spill. I så måte kan man reflektere over hvorvidt digitale teknologiers gamifisering enklere enn papirbaserte teknologier kan komme til å forsterke de kulturelle normene om at det riktige er det viktige når det gjelder skriftspråk.

\section{Avslutning}

Analysen har vist at kommersielle produsenter av abc-apper for norskspråklige førskolebarn særlig vektlegger aktiviteter som gir erfaring med lyd-bokstav-koplinger, bokstavutforming og staving, men også hukommelsesaktiviteter, fri tekstproduksjon, lesing og sang. Måtene som aktivitetene er realisert på, viser at literacy-teoriene til de kommersielle aktørene gjør korrekt/ukorrekt til en viktig parameter, og at de i mindre grad gir prioritet til utforskning og lek, særlig lek med språkets estetiske egenskaper. Analysen har videre vist hvordan kvalitet kan forstås i de ulike aktivitetstypene, og diskutert hvordan en begrensa kunnskapsbase og sterk vektlegging av korrekt/ukorrekt kan bidra til å senke kvaliteten.

Det kan være enkelt å se denne artikkelens kritiske refleksjoner over abc-appene som enda et ledd i den velkjente kritikken mot kommersielle aktørers pedagogiske produkter. Kritikk er imidlertid ikke et mål med denne artikkelen; målet er derimot 


\section{G. Kvåle}

økt kunnskap og styrka refleksjonsgrunnlag. Analysen gir dessuten en utfordring til app-produsenter om å oppsøke og utnytte eksisterende kunnskap, samt å se videre enn belønning av riktig/feil. Den gir også en utfordring til fagmiljøene - til oss! - om å gjøre kunnskap om førskolebarns literacy enda bedre tilgjengelig og å vise fram faglig relevante mulighetsrom.

Hva bør så en god abc-app for førskolebarn romme? Oppsummert kan man si at den bør være kunnskapsbasert, slik at man unngår lett unngåelige kvalitetssenkende trekk som bruk av bokstavnavn framfor bokstavlyd, angivelser av ukorrekte bevegelsesmønster for bokstavutforming, og ureflekterte lese- og staveaktiviteter av lydstridige ord. Korrekt staving av ord, særlig lydstridige ord, er generelt ikke vesentlig for førskolebarn. En god app for denne målgruppa bør derimot legge til rette for aktiviteter som kan gi språklig glede, lek og utforskning. Den bør derfor ikke legge unødvendig sterk vekt på banale belønninger av korrekt/ukorrekt handling, men heller på gode vilkår for utforskende verbal og multimodal tekstskaping. De estetiske sidene bør også være gjennomtenkte. Ikke minst er det et stort potensial for å styrke erfaringer med språket som estetisk material gjennom rim, regler og vers.

\section{Forfatteromtale}

Gunhild Kvåle (f. 1979) er førsteamanuensis i nordisk språkvitenskap ved Institutt for nordisk og mediefag på Universitetet i Agder. Forskningsinteressene hennes handler særlig om multimodalitet, literacy og digitale teknologier, og hun har publisert flere norske og internasjonale artikler og bokkapitler om disse samt andre tematikker.

\section{Referanser}

Barne- og familiedepartementet (1996). Rammeplan for barnehagen. Oslo: Barne- og familiedepartementet. Barton, D. (2007). Literacy. An introduction to the ecology of written language (2. utg.). Malden, Mass.: Blackwell Publishing.

Djonov, E. \& van Leeuwen, T. (2018). The power of semiotic software: A critical multimodal perspective. I J. Flowerdew \& J. Richardson (Red.), The Routledge handbook of critical discourse analysis (s. 566-581). London/New York: Routledge.

Djonov, E. \& van Leeuwen, T. (2011). The semiotics of texture: from tactile to visual. Visual Communication, 10(4), s. 541-564. https://doi.org/10.1177/1470357211415786

Dezuanni, M., Dooley, K., Gattenhof, S. \& Knight, L. (2015). iPads in the Early Years. Developing literacy and creativity. London: Routledge.

Flatøy, I. (2010). Den digitale abc-boka - eit kjærkome supplement eller eit godt tidsfordriv? I E. S. Tønnessen (Red.), Sammensatte tekster. Barns tekstpraksis (s. 79-98). Oslo: Universitetsforlaget.

Hagtvet, B. E. (2004). Språkstimulering. Tale og skrift i førskolealder. Oslo: Cappelen Akademisk Forlag. Hekneby, G. (2011). Skrive - lese - skrive. Begynneropplaring i norsk (3. utg.). Oslo: Universitetsforlaget. Høigård, A. (2013). Barns språkutvikling - muntlig og skriftlig. Oslo: Universitetsforlaget.

Kress, G. \& Jewitt, C. (Red.). (2003). Multimodal literacy. New York: Peter Lang.

Kulbrandstad, L. I. (2018). Lesing i utvikling. Teoretiske og didaktiske perspektiver (2. utg.). Bergen: Fagbokforlaget/ LNU.

Kunnskapsdepartementet (2006). Rammeplanforbarnehagensinnholdogoppgaver. Oslo: Kunnskapsdepartementet. Kunnskapsdepartementet (2017). Rammeplan for barnehagen - innhold og oppgaver. Oslo: Utdanningsdirektoratet. 
Laursen, H. P. (2009). Møder med skriftsprog - et socialsemiotisk perspektiv på tidlig skriftsprogtilegnelse. I L. Holm \& H. P. Laursen (Red.), En bog om sprog - $i$ daginstitutioner. Analyser af sproglig praksis (s. 77-100). København: Danmarks Pædagogiske Universitetsforlag.

Lorentzen, R. T. (1997). Skriftspråkstimulering i førskolealder. I I. Austad (Red.), Mening i tekst. Teorier og metoder i grunnleggende lese- og skriveopplering (s. 173-216). Oslo: LNU/Cappelen Akademisk Forlag.

McManis, L. D. \& Gunnewig, S. B. (2012). Finding the Education in Educational Technology with Early Learners. Young Children, 67(3), 14-24.

McTigue, E. \& Uppstad, P. H. (2019). Spelereglar for digitale dataspel. Norsklceraren 2, 1-13.

Poulsen, S. V., Kvåle, G. \& van Leeuwen, T. (2018). Special Issue: Social media as semiotic technologies. Social Semiotics, 28(5), 593-600. https://doi.org/10.1080/10350330.2018.1509815

Runestad, A. K. (2015). Intensjoner, adaptasjoner og leserposisjoner. En studie av pedagogiske skjermtekster for den begynnende lese- og skriveoppleringa, og av hvordan barn $i$ første klasse engasjerer seg $i$ og med dem (Doktoravhandling). Norges teknisk-naturvitenskapelige universitet, Trondheim.

Semundseth, M. \& Hopperstad, M. H. (Red.). (2013). Barn lager tekster. Om barns tidlige tekstproduksjon og de voksnes betydning. Oslo: Cappelen Damm Akademisk.

Selås, M. (2018). Å skrive for hand. I K. Breivega \& M. Selås (Red.), Skriveboka. Innføring $i$ skriveopplcering (s. 155-168). Oslo: Det Norske Samlaget.

Skjelbred, D. (2017). Norsk larebokhistorie. Allmueskolen, folkeskolen, grunnskolen 1739-2013. Oslo: Universitetsforlaget.

Skyggebjerg, A. K. (2018). Til gavn og fornøjelse for de små - didaktik og æstetik i ABC-billedbøger på vers. Uddannelseshistorie, 52, 59-79.

Smidt, J. (2013). Barns vei til literacy. I M. Semundseth \& M. H. Hopperstad (Red.), Barn lager tekster. Om barns tidligere tekstproduksjon og de voksnes betydning (s. 15-28). Oslo: Cappelen Damm Akademisk.

Traavik, H., Ulland, G. \& Bjørkvold, T. (2013). Arbeidsmåtar i skriftspråksopplæringa på småskolesteget. I H. Traavik \& B. K. Jansson (Red.), Norskboka 1. Norsk for grunnskolelcerarutdanning 1-7 (s. 71-96). Oslo: Universitetsforlaget.

Tønnessen, E. S. (2015). Analytisk blikk på mediet i analyse av multimodal kommunikasjon. I G. Kvåle, E. Maagerø \& A. Veum (Red.), Kontekst, språk og multimodalitet. Nyere sosialsemiotiske perspektiver (s. 25-40). Bergen: Fagbokforlaget.

Tønnessen, E. S. \& Vollan, M. (2010). Begynneropplcering i en sammensatt tekstkultur. Oslo: Cappelen Damm Høyskoleforlaget.

van Leeuwen, T. (2005). Introducing social semiotics. London: Routledge.

Valvatne, H. \& Sandvik, M. (2007). Barn, språk og kultur. Språkutvikling fram til sjuårsalderen. Oslo: Cappelen Akademisk Forlag.

Vollan, M. (2010a). Med geit for g-kritiske blikk på læremidler for de minste. I D. Skjelbred \& B. Aamodtsbakken (Red.), Faglig lesing $i$ skole og barnehage (s. 261-278). Oslo: Novus forlag.

Vollan, M. (2010b). Enkel og morsom læring? Kritiske blikk på læremidler til bruk utenfor skolen for barn mellom fire og ni år. I E.S. Tønnessen \& M. Vollan: Begynneropplcering $i$ en sammensatt tekstkultur (s. 187-212). Oslo: Cappelen Damm Høyskoleforlaget.

Zhao, S., Djonov, E. \& van Leeuwen, T. (2014). Semiotic technology and practice. A multimodal social semiotic approach to PowerPoint. Text E Talk 34(3), 349-375. https://doi.org/10.1515/text-2014-0005 